\title{
ON THE ORIGIN OF STRATIFIED DEBRIS IN ICE CORES FROM THE BOTTOM OF THE ANTARGTIC ICE SHEET
}

\author{
By A. J. Gow, \\ (U.S. Army Cold Regions Research and Engineering Laboratory, Hanover, New \\ Hampshire 03755, U.S.A.) \\ S. Epstein,
}

(Division of Geological and Planetary Sciences, California Institute of Technology, Pasadena, California 9 I rog, U.S.A.)

and W. SHeEhy

(U.S. Army Cold Regions Research and Engineering Laboratory, Hanover, New
Hampshire 03755, U.S.A.)

Abstract. Cores from the bottom $4.83 \mathrm{~m}$ of the Antarctic ice sheet at Byrd Station contain abundant stratified debris ranging from silt-sized particles to cobbles. The nature and disposition of the debris, together with measurements of the physical properties of the inclosing ice, indicate that this zone of dirt-laden ice originated by "freezing-in" at the base of the ice sheet. The transition from air-rich glacial ice to ice practically devoid of air coincided precisely with the first appearance of debris in the ice at $4.83 \mathrm{~m}$ above the bed. Stable-isotope studies made in conjunction with gas-content measurements also confirm the idea of incorporation of basal debris by adfreezing of melt water at the ice-rock interface. It is suggested that the absence of air from basal ice may well constitute the most diagnostic test for discriminating between debris incorporated in a melt-refreeze process and debris entrapped by purely mechanical means, e.g. shearing. We conclude from our observations on bottom cores from Byrd Station that "freezing-in" of basal debris is the major mechanism by which sediment is incorporated into polar ice sheets.

RÉsumé. Sur l'origine des sédiments stratifiés dans les carottes de glace provenant du fond de la calotte glaciaire Antarctique. Des carottes provenant des 4,83 derniers mètres avant le fond de la calotte Antarctique à la station Byrd contiennent une grande quantité de matériaux solides par couches stratifiées allant de la taille des grains de limon à celle de galets. La nature et la disposition de ces sédiments, ainsi que la mesure des propriétés physiques de la glace qui les emballe, indiquent que cette zone de glace sale a pour origine le gel au fond à la base de la calotte. La transition entre la glace de glacier riche en air à la glace pratiquement dépourvue d'air coïncide précisément avec la première apparition de sédiment dans la glace à $4,83 \mathrm{~m}$ au dessus du lit. Les études d'isotope stables faites en liaison avec les mesures de teneur en gaz confirment l'idée d'une incorporation des débris du fond par regel de l'eau de fusion à l'interface glace-roche. On suggère que l'absence d'air dans la glace de fond peut bien constituer le meilleur test pour distinguer entre les sédiments incorporés dans un processus fusion-regel et ceux qui sont captés par des moyens purement mécaniques par exemple par cisaillement. Nous concluons de nos observations sur les carottes du fond issues de la station Byrd que le gel au fond des sédiments est le mécanisme principal d'incorporation des sédiments dans les calottes glaciaires polaires.

Zusammenfassung. Über den Ursprung geschichteten Schuttes in Eiskernen vom Untergrund des antarktischen Eisschildes. Kerne aus den untersten $4,83 \mathrm{~m}$ des antarktischen Eisschildes bei der Byrd-Station enthalten reichlichen, geschichteten Schutt von der Grösse verschlämmter Partikel bis zu der von Steinen. Die Art und Anordnung des Schuttes lassen zusammen mit Messungen der physikalischen Eigenschaften des einschliessenden Eises darauf schliessen, dass diese Zone verschmutzten Eises durch Einfrieren am Grunde des Eisschildes entstanden ist. Der Übergang von luftreichem zu praktisch luftleerem Eis fällt genau mit dem ersten Auftreten von Schutt im Eis, 4,83 m über dem Bett, zusammen. Studien mit stabilen Isotopen, die in Verbindung mit Gasgehaltsmessungen angestellt wurden bestätigen ebenfalls die Vorstellung von der Aufnahme des Untergrundschuttes durch Anfrieren von Schmelzwasser an der Grenzfläche zwischen Eis und Fels. Es wird vermutet, dass das Fehlen von Luft im Eis das sicherste Kriterium für die Unterscheidung zwischen Schutt, der durch einen Schmelz- und Regelationsprozess ins Eis gelangte, und solchem, der durch rein mechanische Vorgänge, z.B. Scherung, aufgenommen wurde, darstellt. Die Beobachtungen an Tiefkernen von der Byrd-Station lassen darauf schliessen, dass das Einfrieren von Schutt der wichtigste Mechanismus ist, durch den Sedimente in polare Eisschilde gelangen.

\section{INTRODUCTION}

During the latter stages of drilling of the $2 \mathrm{I} 64 \mathrm{~m}$ deep hole at Byrd Station, West Antarctica, liquid water was encountered at the ice-rock interface (Gow and others, 1968), clear evidence that the bottom of the ice sheet at this location is at the pressure-melting point. 
Drilling was extended to a depth of $1.3 \mathrm{~m}$ below the ice-rock interface but all attempts to retrieve a subglacial core were unsuccessful. It is suspected that the sub-ice material is composed of unconsolidated sediments, such as till or gravel rather than compact bedrock. A sample of melt water from the bottom of the drill hole yielded a specific conductance of $45 \mu \mathrm{S} / \mathrm{cm}$, a value that greatly exceeds the $\mathrm{I}-2 \mu \mathrm{S} / \mathrm{cm}$ obtained on the glacial ice cores at Byrd Station but a value that is compatible with melt water that has been in contact with till or moraine; it compares favorably, for example, with conductivities obtained by Rainwater
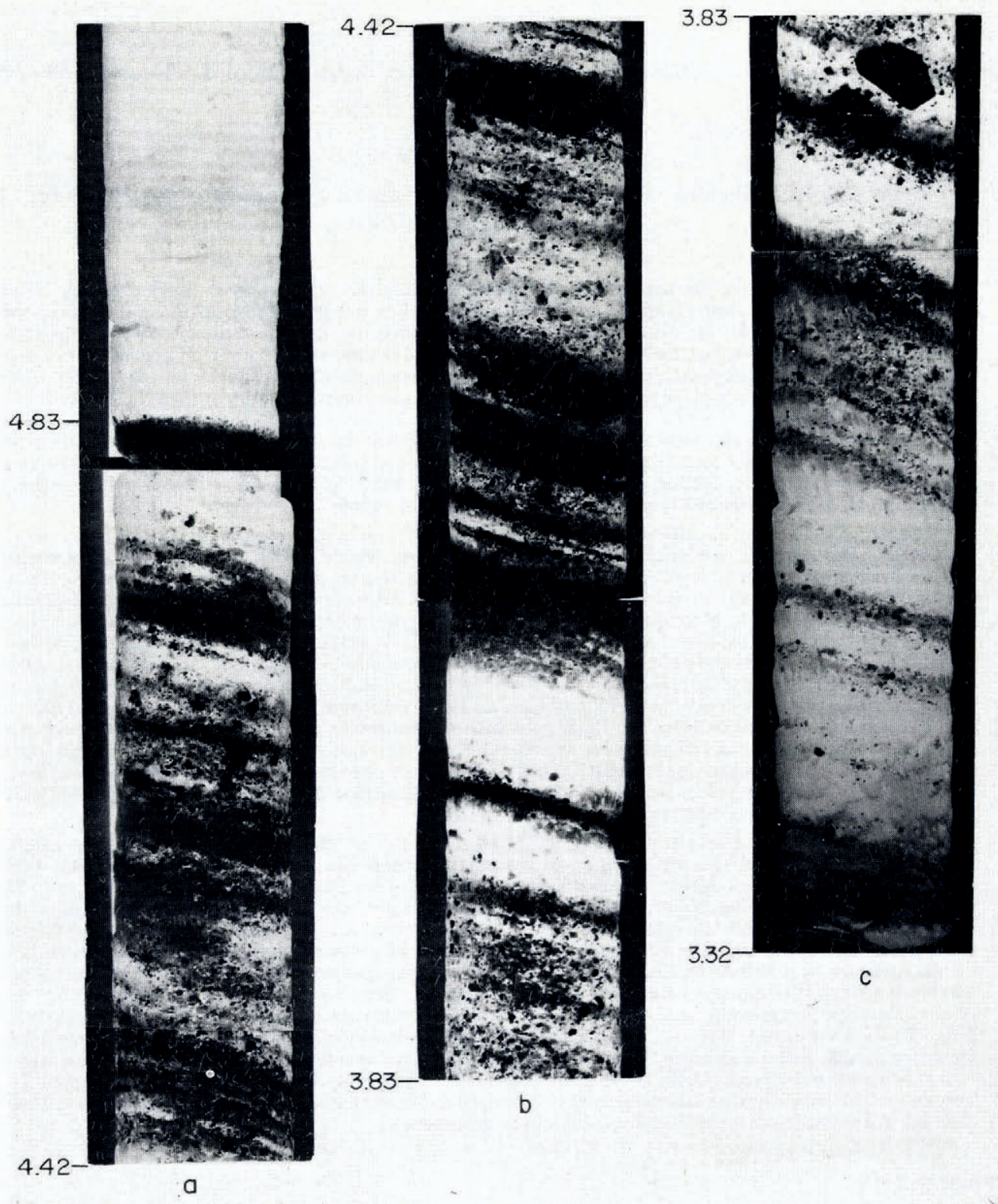

Fig. I. Top of stratified debris zone in a core from the bottom of the Antarctic ice sheet at Byrd Station. Thickness of basal debris zone is $4.83 \mathrm{~m}$; dimensions are in meters from the ice-rock interface. True disposition of ice-debris layers is horizontal; layers appear inclined $\left(I 4^{\circ}\right)$ because of inclined drilling. 
and Guy (196r) for stream waters flowing over till below the snout of Chamberlin Glacier, Alaska.

Examination at the drill site of cores of bottom ice from Byrd Station showed them to contain abundant stratified debris, including layers of clay, sand, and pebbles, and larger fragments of rock occasionally interspersed with bands of clear ice. This dirty ice zone extended from the ice-rock interface to a height of $4.83 \mathrm{~m}$ above the bed. In order to elucidate the origin of this basal debris zone, we have examined both the nature and disposition of the debris and the physical properties of the inclosing ice. Our results, which form the basis of this paper, indicate that this zone of dirty ice originated by "freezing-in" at the base of the ice sheet.

\section{RESUlTS AND DISGUSSION}

\section{Bottom-core stratigraphy}

Detailed examinations of bottom-core stratigraphy were made with the aid of a light table that transmits light through the core from fluorescent tubes placed beneath the core. Stratigraphic structure of the section of core extending from $5.04 \mathrm{~m}$ to $3.32 \mathrm{~m}$ above the bed is illustrated in Figure $\mathrm{I}$. In this instance, the layering appears significantly inclined because of a $14-15^{\circ}$ inclination of the hole incurred during drilling. Inclinometer measurements performed in conjunction with the drilling indicate that the true disposition of the debris bands is horizontal. Debris is composed predominantly of clay-, sand-, and pebble-size particles interspersed with cobbles, that include fragments of larger rock pieces only partially contained within the limited dimensions of the $10 \mathrm{~cm}$ diameter core. Most pebbles were actually sedimentary aggregates composed of clay and sand held together by interstitial ice and best described as mud clots. The true identity of these pebble-like clots was established only after they were observed to disintegrate entirely on melting. Up to $\mathrm{I} \mathrm{cm}$ in diameter, these clots occur either concentrated in bands, several centimeters thick, or dispersed as discrete particles throughout the ice (Fig. 2). It is suspected that the clots may have been formed during the freezing of slurries or muddy water.

X-ray diffraction analysis was used to determine the light-mineral compositions of a number of pebble-like clots and several samples of dispersed sediment in the sand to clay range. These analyses yielded a variety of mineral species which in the case of the pebble-iike clots generally included quartz, plagioclase, muscovite, chlorite, and kaolinite. The samples of dispersed sediment generally contained potash feldspar in addition to the combination of light minerals listed above.

A section of core containing a large fragment of granite is illustrated in Figure 3. This fragment, measuring approximately $8 \mathrm{~cm}$ in its longest dimension, appears to be contained within a band of fine-grained debris; it is immediately underlain by less dirty ice and overlain by a $4 \mathrm{~cm}$ band of clear ice that grades rapidly into a zone of ice with a high debris content. Elongated and tabular fragments tend to be oriented within the plane of stratification.

\section{Ice-debris contents}

Ice-debris contents were obtained on three separate pieces of core measuring $15^{-22} \mathrm{~cm}$ in length. These measurements yielded debris weight percentages of $12.0,15 \cdot 7$, and $15 \cdot 3$. These values all yield debris volume concentrations of less than $7 \%$. However, it is of interest in this regard to note that even small amounts of dispersed debris in cores can lead to deceptively dirty looking ice though actual measurements of debris concentration invariably yield values that are much smaller than appearances would otherwise indicate.

The occasional occurrence of dirt-free ice in the bottom cores at Byrd Station can probably be attributed to freezing on of water at places where the bedrock surface was substantially free of loose debris. 

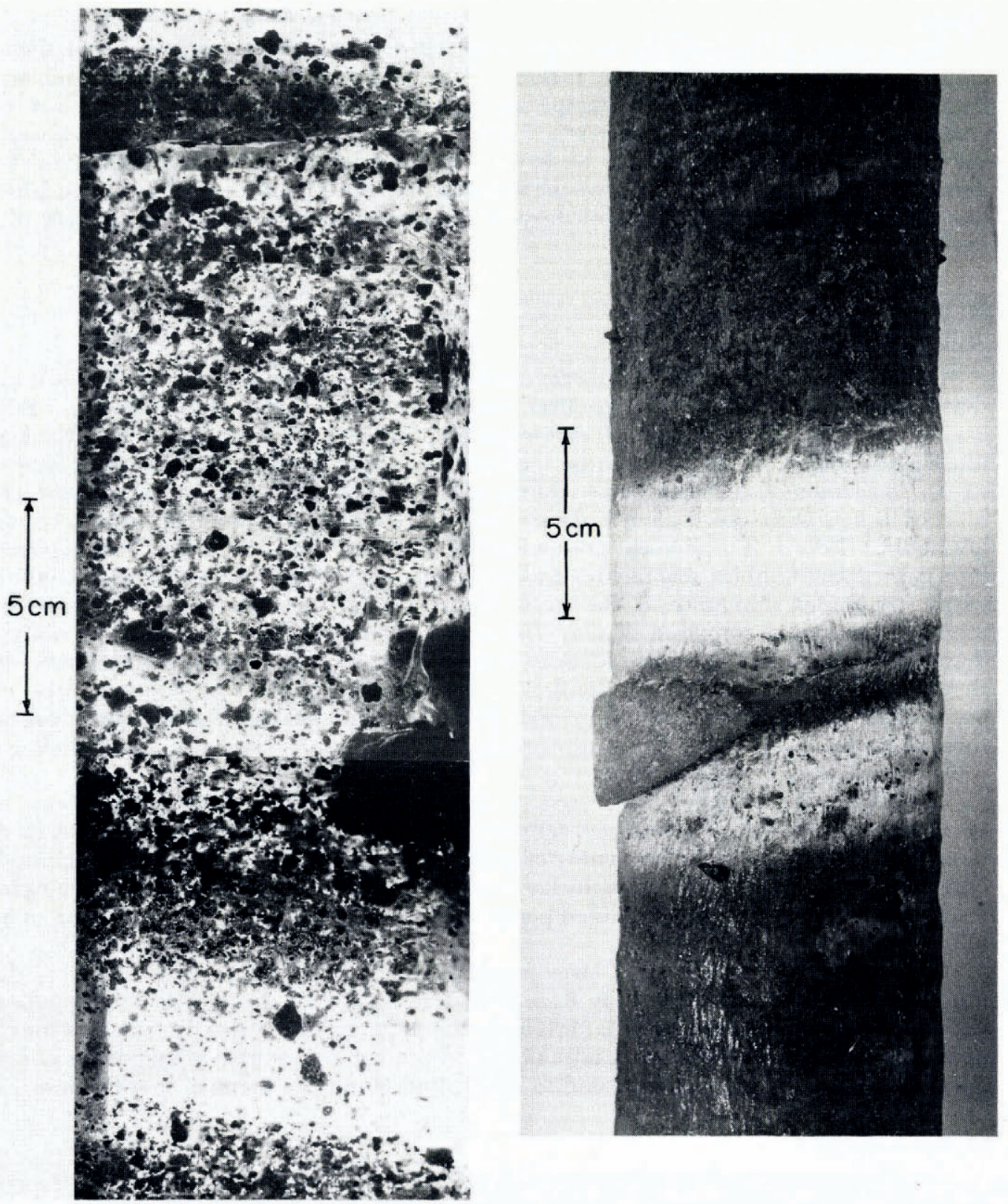

Fig. 2. Close-up of particle (mainly mud clot) distribution

Fig. 3. Ice-dirt band structure and granite fragment in core patterns in a basal ice core, Byrd Station, Antarctica. from basal debris zone, Byrd Station, Antarctica. 


\section{Petrography of coarser fragments}

Petrographic studies of bottom cores were limited to thin-section examinations of coarser rock fragments, mainly larger pebbles and cobbles, that revealed an assortment of rock types in the basal dirt zone at Byrd Station. Specific types of rock identified included several kinds of granite, quartz-monzonite, basalt, tuff, and arkosic arenite. Photomicrographs of some representative rocks are given in Figure $4 \mathrm{a}-\mathrm{e}$.
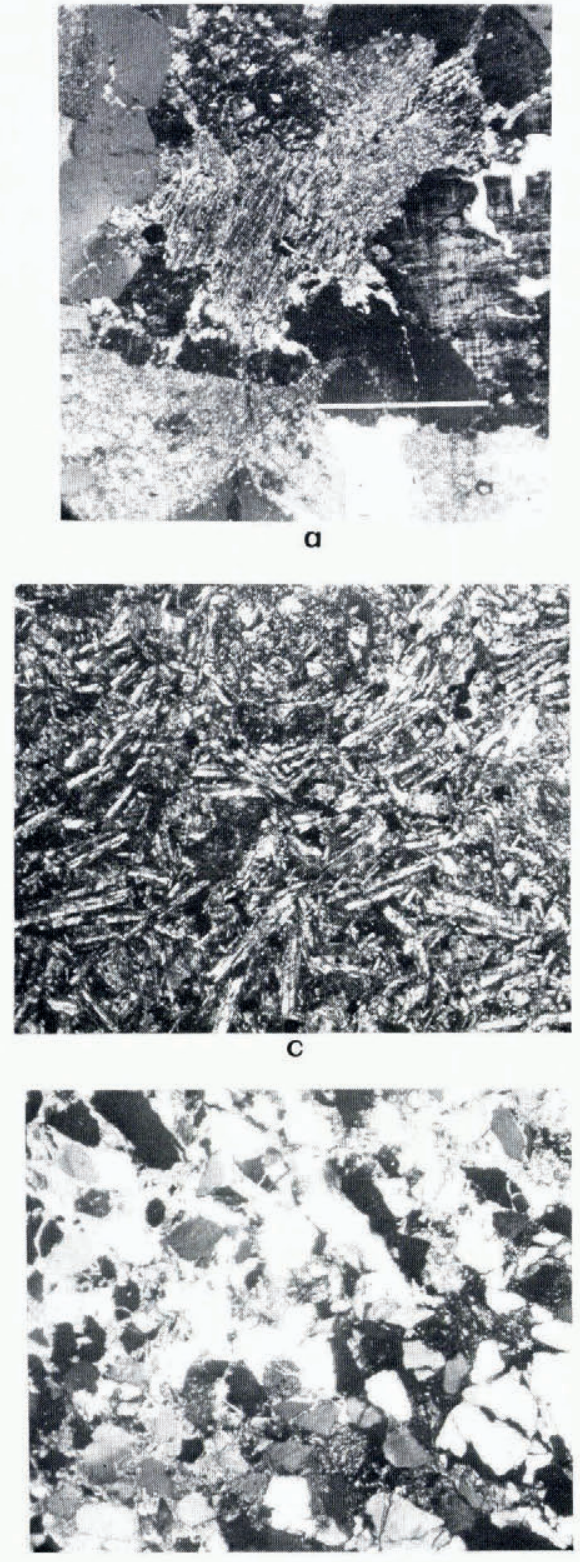
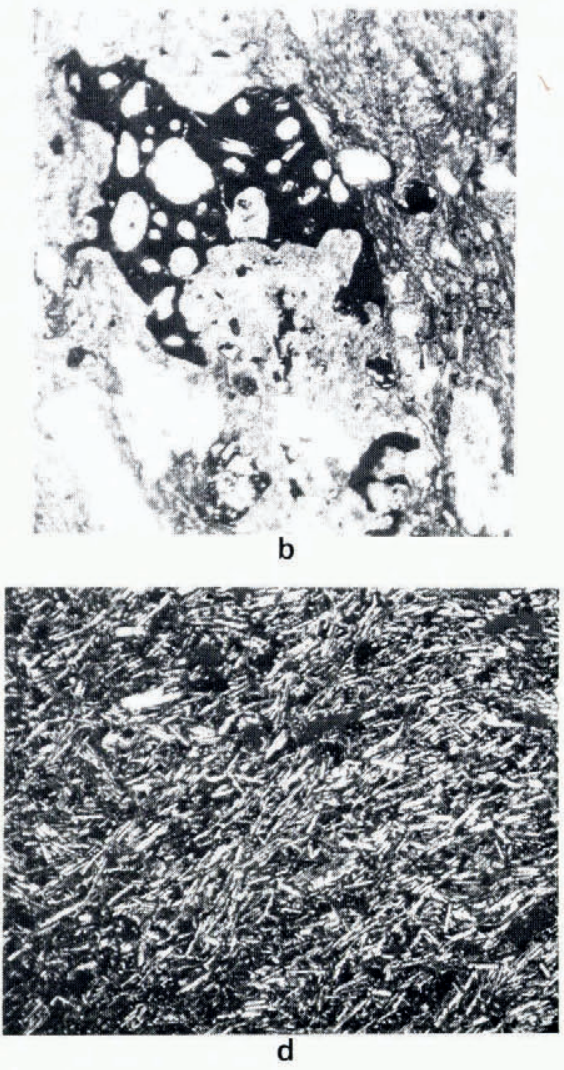

e

Fig. 4. Photomicrographs of some representative rocks from the basal debris zone, Byrd Station, Antarctica. a. Quartz-monzonite; $b$. Tuff; $c$ and $d$. Basalt; $e$. Arkosic arenite. All photomicrographs taken at the same magnification. Scale bar for the quartz-monzonite section (a) measures $1 \mathrm{~mm}$. 
Entrapped air content

Gas-volume contents were measured by Gow and Williamson (1975) on cores from 20 different levels in the ice sheet, including four samples from the basal debris zone. These tests involved melting an accurately measured volume of ice under kerosene and collecting the evolved gas in a burette. The technique has been fully described by Langway (1958).

Only in the bottom $4.83 \mathrm{~m}$ of ice core was the air content of ice observed to diminish to practically zero. Gas contents measured at four separate levels in these bottom cores all

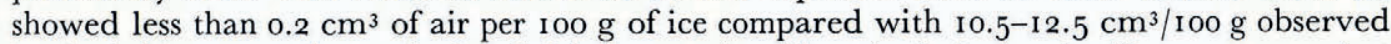
in glacial ice cores above the basal debris zone (see Fig. 5). It is also significant to note that the transition from air-rich glacial ice to ice virtually devoid of air coincides precisely with the first appearance of stratified debris in the cores. This observation certainly lends strong support to the idea that the basal debris zone at Byrd Station originated by refreezing of melt water at the ice-rock interface and that freezing occurred slowly enough to allow for sub-
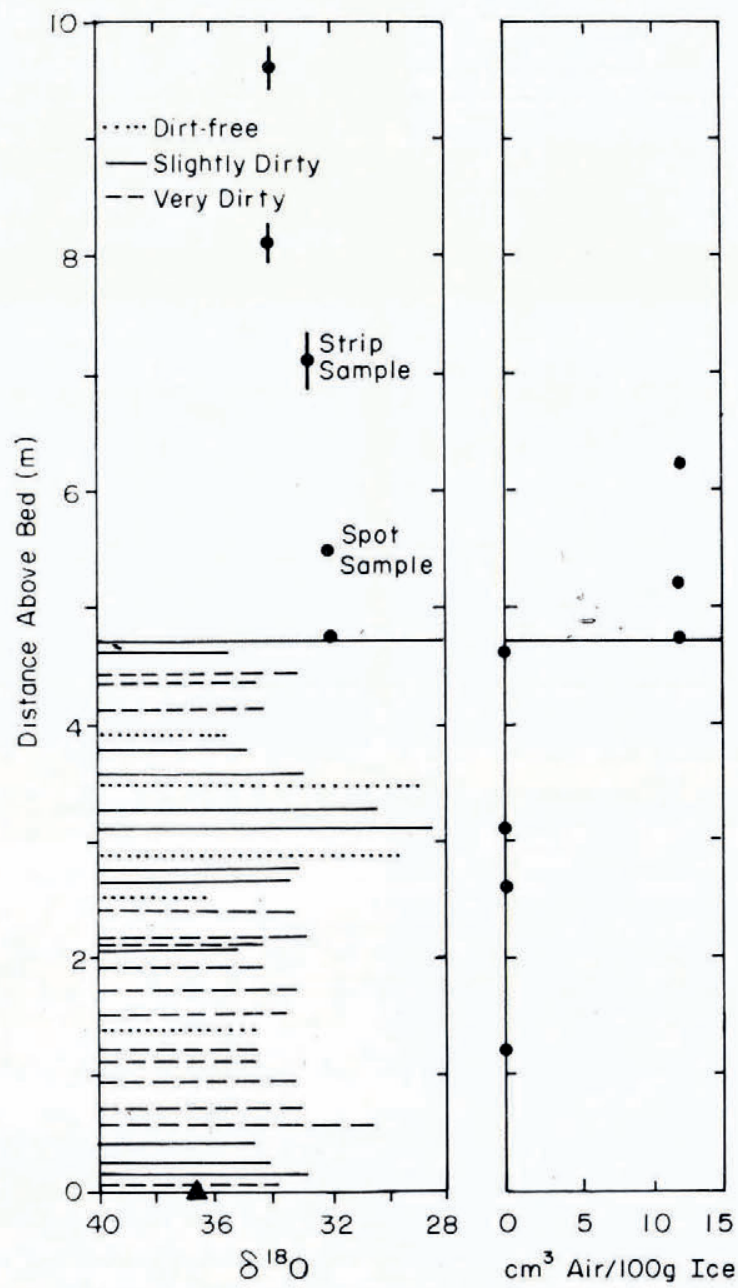

Fig. 5. $\delta^{18} \mathrm{O}$ and entrapped-gas measurements in the bottom $10 \mathrm{~m}$ of ice at Byrd Station, Antarctica. Transition between true glacial and basally accreted ice occurs at $4.83 \mathrm{~m}$ above the bed. Note that dimensions of vertical strip samples are denoted by length of line through data points; spot samples measured 4-5 cm long; $\mathbf{\Delta}$ basal melt water. 
stantially complete rejection of any air dissolved in the water. Lorius and others (Ig68) have observed air-free ice at the bottom of the ice sheet in East Antarctica which they also have attributed to the freezing of water at the glacier bed.

\section{Stable-isotope analysis}

Results of stable-isotope analysis of the debris-laden bottom ice at Byrd Station are included in Figure 5. The plotted values, including the sample of basal melt water, represent the deviation $(\delta)$ of oxygen $\left({ }^{18} \mathrm{O} /{ }^{16} \mathrm{O}\right)$ ratios from the corresponding ratios for standard mean ocean water (SMOW). The $\delta$ values are here expressed in per mil units as defined by Epstein and Mayeda (1953). Original measurements of $\delta^{18} \mathrm{O}$ values of selected samples from the entire ice-sheet core at Byrd Station have been given by Epstein and others (1970).

The mean $\delta^{18} \mathrm{O}$ value of the bottom ice samples is similar to that obtained from samples of clean air-rich glacial ice, which would imply that the melt water being supplied to the icerock interface is of fairly local origin. However, variations of $\delta^{18} \mathrm{O}$ values among closely spaced samples from the debris-laden zone generally exceed those observed in glacial debris-free ice above $4.83 \mathrm{~m}$. Such variation might be attributed either to small isotopic fractionation effects incurred during freezing or to small but significant differences in the isotopic composition of the source water. It is worth noting in this regard that the sample of basal melt water yielded a $\delta^{18} \mathrm{O}$ value about $3 \%$ lower than the average value obtained with ice from the basal debris zone. This observation certainly reinforces the case for bottom freezing, since a $3 \%$ enrichment in the ${ }^{18} \mathrm{O}$ content of these basal ice samples with respect to the $\delta^{18} \mathrm{O}$ values of basal melt water agrees very closely with the magnitude and direction of change reported by O'Neil (1968) for oxygen-isotope fractionation between ice and fresh water. Also, the low $\delta^{18} \mathrm{O}$ values in the basal debris zone attest that this ice (and the basal melt water) is not derived from the freezing of sea-water, even though the ice-rock interface at Byrd Station is approximately $600 \mathrm{~m}$ below sea-level.

There appears to be no systematic relationship between the $\delta^{18} \mathrm{O}$ values and the debris concentrations in the ice.

\section{Conclusions}

It would appear from the nature and disposition of debris particles in the bottom cores at Byrd Station, and from stable-isotope and entrapped-gas content studies of the inclosing ice, that all material within $4.83 \mathrm{~m}$ of the ice-rock interface originated by "freezing-in" of basal melt water. This discontinuity at $4.83 \mathrm{~m}$ is of major glaciological significance because it marks the transition between snow-derived glacial ice above and basally accreted ice below. We have no way of telling if the zone of basally accreted dirty ice was incorporated during a single phase of "freezing-in" or was episodic and interrupted by periods of bottom melting. The occurrence of water at the ice-rock interface simply confirms the fact that the basal ice is still at the pressure-melting point. We have no evidence whatsoever to indicate any "shearingin" of rock materials. We would suggest that any critical evaluation of sediment entrapment mechanisms should include measurement of the entrapped gas content of the ice. Absence of air might well constitute the simplest test for discriminating between debris incorporated in a melt-refreeze process and debris entrained by purely mechanical means, such as shearing, which should not affect the air content of the ice. We also subscribe to the views advanced by Weertman (I96I, I966) and Boulton (1970) that "freezing-in" of debris is a major mechanism of entrapment of basal debris, especially in cold polar glaciers where the bottom of the ice sheet is at the pressure-melting temperature and where the temperature gradient above the ice-rock interface is sufficient to conduct away the latent heat of freezing of the basal melt water. 


\section{REFERENCES}

Boulton, G. S. 1970. On the origin and transport of englacial debris in Svalbard glaciers. Fournal of Glaciology, Vol. 9 , No. 56, p. $213-29$.

Epstein, S., and Mayeda, T. K. 1953. Variation of $\mathrm{O}^{18}$ content of waters from natural sources. Geochimica et Cosmochimica Acta, Vol. 4, No. 5, p. 21 3-24.

Epstein, S., and others. 1970. Antarctic ice sheet: stable isotope analysis of Byrd Station cores and interhemispheric climatic implications, by S. Epstein, R. P. Sharp, and A. J. Gow. Science, Vol. 168, No. 3939, p. $1570-72$.

Gow, A. J., and Williamson, T. C. 1975. Gas inclusions in the Antarctic ice sheet and their glaciological significance. Fournal of Geophysical Research, Vol. 8o, No. 36, p. $5101-08$.

Gow, A. J., and others. 1968. Antarctic ice sheet: preliminary results of first core hole to bedrock, by A. J. Gow, H. T. Üeda, and D. E. Garfield. Science, Vol. 16r, No. 3845, p. Ior I-13.

Langway, C. C., jr. 1958. Bubble pressures in Greenland glacier ice. Union Géodésique et Géophysique Internationale. Association Internationale d'Hydrologie Scientifique. Symposium de Chamonix, 16-24 sept. 1958, p. 336-49. (Publication No. 47 de l'Association Internationale d'Hydrologie Scientifique.)

Lorius, C., and others. 1968 . Densité de la glace et étude des gaz en profondeur dans un glacier antarctique, [par] C. Lorius, D. Raynaud, et L. Dolle. Tellus, Vol. 20, No. 3, p. 449-6o.

O'Neil, J. R. I 668 . Hydrogen and oxygen isotope fractionation between ice and water. Fournal of Physical Chemistry, Vol. 72, No. 10, p. 3683-84.

Rainwater, F. H., and Guy, H. P. 1961. Some observations of the hydrochemistry and sedimentation of the Chamberlin Glacier area, Alaska. U.S. Geological Survey. Professional Paper 44-C.

Weertman, J. 1961. Mechanism for the formation of inner moraines found near the edge of cold ice caps and ice sheets. Fournal of Glaciology, Vol. 3, No. 30, p. 965-78.

Weertman, J. Ig66. Effect of a basal water layer on the dimensions of ice sheets. Fournal of Glaciology, Vol. 6, No. 44 , p. $19^{1-207}$.

\section{DISGUSSION}

A. Dreimanis: As your photographs of the core showed some shear-like structures, I am wondering whether you have considered and tested the shearing mechanism as an alternative process for incorporating the basal debris. Have you done fabric studies of the ice and debris particles? The "mud balls" shown on the photograph are mostly angular and sub-angular, and suggest breakage of the mud during or after incorporation-what usually occurs when shearing does the incorporation. Could not the gases have been pressed out by shearing?

A. J. Gow: This is a good point. However, all evidence we have presented supports the "freeze-on" mechanism to explain the origin of stratified debris in basal ice at Byrd Station. We have not studied the $c$-axis fabrics of basal ice mainly because of the great difficulty in preparing samples for thin-section analysis. But even if shearing is now occurring in the basal ice, the existence of a shear fabric would not be conclusive since shearing could have occurred after the incorporation of debris. It is difficult for me to conceive how shearing could completely expel gases from ice containing $10 \%$ by volume of air (at s.t.p.). It is much simpler (and in conformity with other evidence) for air to be rejected during the melt-freeze process.

R. P. Goldthwait: Did you make mechanical analyses of the basal debris? This might indicate any selective freeze-on of debris.

Gow: No. But it is noticeable that most material is finer than it looks because there are many clusters ("mud balls") of very fine material. These "mud balls" are simply aggregations of fine-grained particles (sand and clay) bound together by ice. They disintegrate completely on melting. 